九州大学学術情報リポジトリ

Kyushu University Institutional Repository

Size-frequency Distributions of Living

Population and Dead Shell Assemblages of Macoma (Macoma) incongrua (MARTENS) on an Intertidal Mud-F lat in North Kyushu

Shimoyama, Shoichi

Faculty of Science, Kyushu University

https://doi.org/10.5109/1546099

出版情報：九州大學理學部紀要：Series D, Geology. 25 (2)，pp.271-287，1984-11-15. Faculty of Science, Kyushu University バージョン：

権利関係 : 
Mem. Fac. Sci., Kyushu Univ., Ser. D, Geol., Vol. XXV, No. 2, pp. 271-287, text-figs. 1-12, tables 1-2, November 15,1984

\title{
Size-frequency Distributions of Living Population and Dead Shell Assemblages of Macoma (Macoma) incongrua (MARTENS) on an Intertidal Mud-Flat in North Kyushu
}

\author{
Shoichi SHIMOYAMA
}

\begin{abstract}
The intertidal flat of the small inlet of Tsuyazaki, Fukuoka, western Japan, supports one of the highest population density of a deep burrower, Macoma (Macoma) incongrua (MARTENS), ever recorded. Death of the clams at burrowing stage is concentrated in the mature size-classes of living population. And the primary pattern of size-frequency distribution of the dead shells derived directly from the living population at burrowing stage shows a symmetrical distribution centering around the mature size-classes of the species. This feature of primary pattern of size-frequency distribution is well demonstrated in the greater part of the dead shell assmblages in bottom sediments of the inlet. A slight size-modification of the size-frequency distribution of dead shells is observed in this species. The important factor controlling size-modification in this species is residual concentration of dead shells as a result of washing out of the sediment by tidal currents. This modification increases the variance and size-ranges without a drastic change of the form of the size-frequency histograms.
\end{abstract}

\section{Introduction}

One of the main themes in a palaeoecological study is how to restore the lives of extinct organisms through a study of fossils. Palaeontologists must evaluate how much biological information on the ancient life is preserved in individual fossil and/or fossil assemblages. If size-frequency distribution of intraspecific assemblages of fossil animals can provide an insight into the relative age distribution, it may be possible to infer, by analogy with populations of modern organisms, the population structure of the extinct organisms.

On the basis of DEEVEY's works $(1947,1950)$ on the mortality rate of many shallow-sea molluscs, Bоucot (1953) first introduced into palaetontology the method to reconstruct the survivorship curve of fossil molluscan species by means of size-frequency distribution analysis. This method has been subsequently applied in many palaeoecological works. Noteworthy examples are works on fossil brachiopods by VeEvers (1959), RUDWICK (1962), ZIEGLER et al. (1966), BROOKFIELD (1973), RICHARD and BAMBACH (1975), and THAYER (1977) ; fossil molluscs by Mitra (1958), Craig and Hallam (1963), FagerStrom (1964), Craig and Oertel (1966), Craig (1967), Hallam (1967), Stum(1975), and HOFFMAN (1976); and also on fossil vertebrates by KURTEN (1964),

Manuscript received July 20, 1984. 
and RICHMOND (1965).

BoucoT's method may be well applicable to such deep burrowing or sessile benthic animals as ostreids and brachiopods, because we can decide easily from the mode of occurrence whether a fossil sample represents an in situ population or not. On the contrary, careful observation should be paid to the mode of occurrence of epifaunal or shallow burrowing vagile molluses which live under the unstable hydrodynamic condition. If the water movement gradually become strong, primary pattern of the size-frequency distribution of a dead shell assemblage will be modified by selective transportation of small shells (FAGERSTROM, 1964).

Craig and Hallam (1963), Fagerstrom (1964), Craig and Oertel (1966), HALlaM 1967) and HALLAM (1972) mentioned that the pattern of size-frequency distribution of an intraspecific assemblage of dead shells or a fossil shell assemblage is determined by the mortality rate and growth rate of the living population, size-selective modification of dead shells by physical and biological agents before final burial on the sea bottom, and size-selective chemical destruction of the dead shells through a process of diagenesis after final burial in sediments. The extent of the post-mortem modification is shown by the difference between the two patterns of size-frequency distributions or size-specific survivorship curves of the dead shells derived dirctly from th living population and that of the dead or fossil shells in sediments.

Bouc0T (1953), FAgerstrom (1964) and HALLAM (1967) reported that many of size-frequency distribution patterns of dead shells in marine substrates do not always keep the primary patterns derived directly from natural death of the living populations and are more or less modified before the final burial, and that the modification proceeds according to a general rule. They recognized the difference between autochthonous "life asemblages" (sense Boucot, 1953) and allochthonous death assemblages (sense BoucoT, 1953) on the basis of the generalized patterns of the size-frequency distribution. However, as is already mentioned by themselves there is a possibility that the primary patterns of sizefrequency distribution of dead shells and the survivorship curves of the living populations changes species by species as a result of ecological features of respective species and environmental conditions.

Thus, in order to reconstruct survivorship curves of fossil populations of the extinct animals, we must consider the effect of post-mortem modification of size-frequency distributions by physical, chemical and biological factors.

Accordingly it is essential important in the study of palaeoecology to clear up the cause and mode of post-mortem modification of primary pattern of sizefrequency distribution.

The present study is intended as a contribution towards these ends. As the first approach to their solutions, the population growth pattern of deep burrower, Macoma (Macoma) incongrua (MARTENS), in the small inlet at Tsuyazaki, North Kyushu is analyzed in the light of population ecology. The formation and modification of the size-frequency distributions of the species in the inlet since burrowing life are investigated in detail. The results are presented in this paper. 


\section{Description of study area}

The small inlet named "Irie" in Tsuyazaki, Munakata-gun, Fukuoka Prefecture, West Japan, where this work has been carried out, is located $20 \mathrm{Km}$ north of Fukuoka City (Fig. 1). This narrow bay is about $2.0 \mathrm{Km}$ in maximum length extending from north to south, and its mouth opens to the south to Genkainada Sea.

The tidal range is about $2.0 \mathrm{~m}$ at spring tides. At the low tide an extensive tidal-flat is uncovered, through which a main channel and its tributaries take their courses. The tidal flat may be classified into sand flat, muddy sand flat, and mud flat on the basis of bottom sediment type and the first and third types are developed in much wider area than the second one (Shimoyama, $1979 \mathrm{~b})$. Tidal stream in the channel is so swift that bottom sediments are sometimes washed to leave concentrated molluscan shells on the bottom.

Sea water temperature in inner bay ranges from about $6{ }^{\circ} \mathrm{C}$ in February to $34^{\circ} \mathrm{C}$ in July and August.

Two species of sea grass, Zostera, grow thick on the surface of the tidal flat. While Zostera nana Roтн covers mud flats in the inner part of the inlet, Zostera marina LinNaEus grow here and there along the channel in the mouth

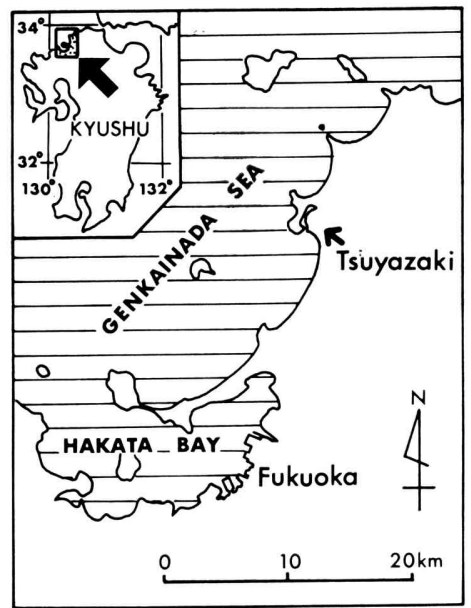

Fig. 1. Locality map of Tsuyazaki in North Kyushu.

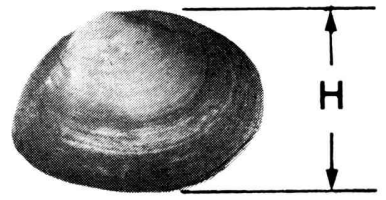

Fig. 2. Measurements of Macoma (Macoma) incongrua (MARTENS). $\mathrm{H}$ : shell-height. 


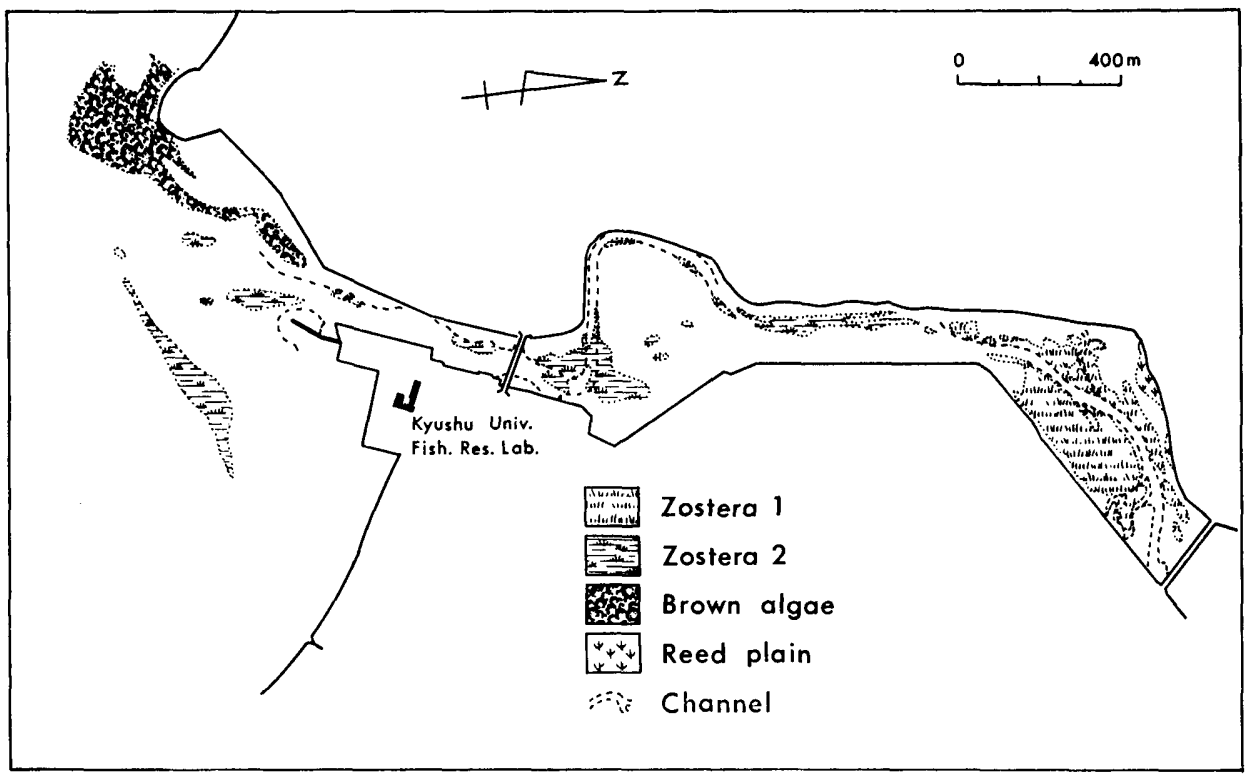

Fig. 3. Map showing the sea grass Zostera zone in the inlet of Tsuyazaki. Zostera 1: Zostera nana, Zostera 2: Zestera marina.

and central part of the inlet (Fig. 3). Clumps of two species of Zostera weaken the tidal current and cause the deposition of muddy material. Furthermore, well-developed subsurface stems of Zostera prevent scouring by tidal currents.

List of the living molluscan species in "Irie" is shown in Table 1. Some molluscan species are regarded as characteristic of inner bay environments. Although the number of species is small, number of individuals of each species is generally large. Dominant benthic molluscan species in this inlet are as follows: Saxostrea echinata (QUOY \& GAIMARD), Ruditapes philippinarum (ADAMS \& REEVE), Cyclina sinensis (GMELIN), Macoma (Macoma) incongrua (MARTENS), Umbonium (Suchium) moniliferum (LAMARCK), Littorina brevicula (Philippi), Cerithideopsilla adjadjariensis (K. Martens), Cerithideopsilla cingulata (GMELIN), Batillaria zonalis (BRUGUİke), Batillaria cumingii (CROSSE), Batillaria multiformis (LISCHKE) and Reticunassa festiva (PowYS).

\section{Material and Methods}

In order to investigate the density of living populations and dead shell assemblages of the species, I have designated a grid of $25 \mathrm{~m} \times 25 \mathrm{~m}$ with an axis parallel to the extension of the inlet. Samples were collected at ach point of intersection of the grid using a $0.25 \mathrm{~m} \times 0.25 \mathrm{~m}$ steel frame $(0.15 \mathrm{~m}$ in depth) (Fig. 4-b). It was first wedged into the sediments to a depth of $0.15 \mathrm{~m}$, and then the contents were dug out. The above mentioned procedure was repeated four times to cover an area of $0.5 \mathrm{~m} \times 0.5 \mathrm{~m}$ which was defined as a sampling unit taking into consideration of the result of test sampling. The sediments were then sieved through an $1 \mathrm{~mm}$ standard sieve. 
Table 1. List of living molluses in the inlet of Tsuyazaki.

Patelloida (Ciazacmea) pygmaea lampanicola (HABE)

Umbonium (Suchium) moniliferum (LAMARCK)

Cantharidus japonicus japonicus (A. ADAMS)

Monodonta labio confusa TAPPARONE-CANEFRI

Lunella coronata coreensis (RECLUZ)

Littorina brevicula (PHILIPPI)

Littorinopsis scabra (LINNAEUS)

Nodilittorina exigua (DUNKER)

Temanella turrita (A. ADAMS)

Cerithideopsilla djadjariensis (MARTIN)

Cerithideopsilla cingulata (GMELIN)

Cerithidea rhizophorum rhizohorum A. ADAMS

Cerithidea ornata A. ADAMS

Batillaria zonalis (BRUGUIÈRE)

Batillaria multiformis (LISCHKE)

Batillaria cumingii (CROSSE)

Eufenella pupoides (A. ADAMS)

Eufenella rufocincta (A. ADAMS)

Diffalaba picta (A. ADAMS)

Clypeomorus humilis (DUNKER)

Reishia clavigera (KUSTER)

Reticunassa festiva (PowYs)

Niotha livescens (PHILIPPI)

Hemifusus ternatanus (GMELIN)

Syrnola cinctella A. ADAMS

Leucotina gigantea (DUNKER)

Pyrgolampros hiradoensis (PILSBRY)

Decolifer insignis (PILSBRY)

Melampus singaporensis PFEIfFer

Nucula paulula A. AdAMS

Barbatia virescens obtusoidea (NYST)

Scapharca subcrenata (LISCHKE)

Musculus (Musculista) senhausia (BENson)

Saxostrea echinata (QUoY \& GAIMARD)

Pillucina (Pillucina) pisidium (DUNKER)

Felaniella sowerbyi KURODA \& HABE

Ruditapes philippinarum (ADAMS \& REEVE)

Circe scripta (LinNAEUS)

Meretrix lusoria RöDING

Cyclina sinensis (GMELIN)

Phacosoma japonicum (REEve)

Coecella chinensis (DEShaYes)

Mactra (Mactra) veneriformis REEVE

Merisca (Pistris) capsoides (LAMARCK)

Moerella rutila (DUNKER)

Macoma (Macoma) incongrua (MARTENS)

Macoma (Macoma) contabulata (DEShAYES)

Solen striclus GoulD

Laternula limicola (REEVE) 

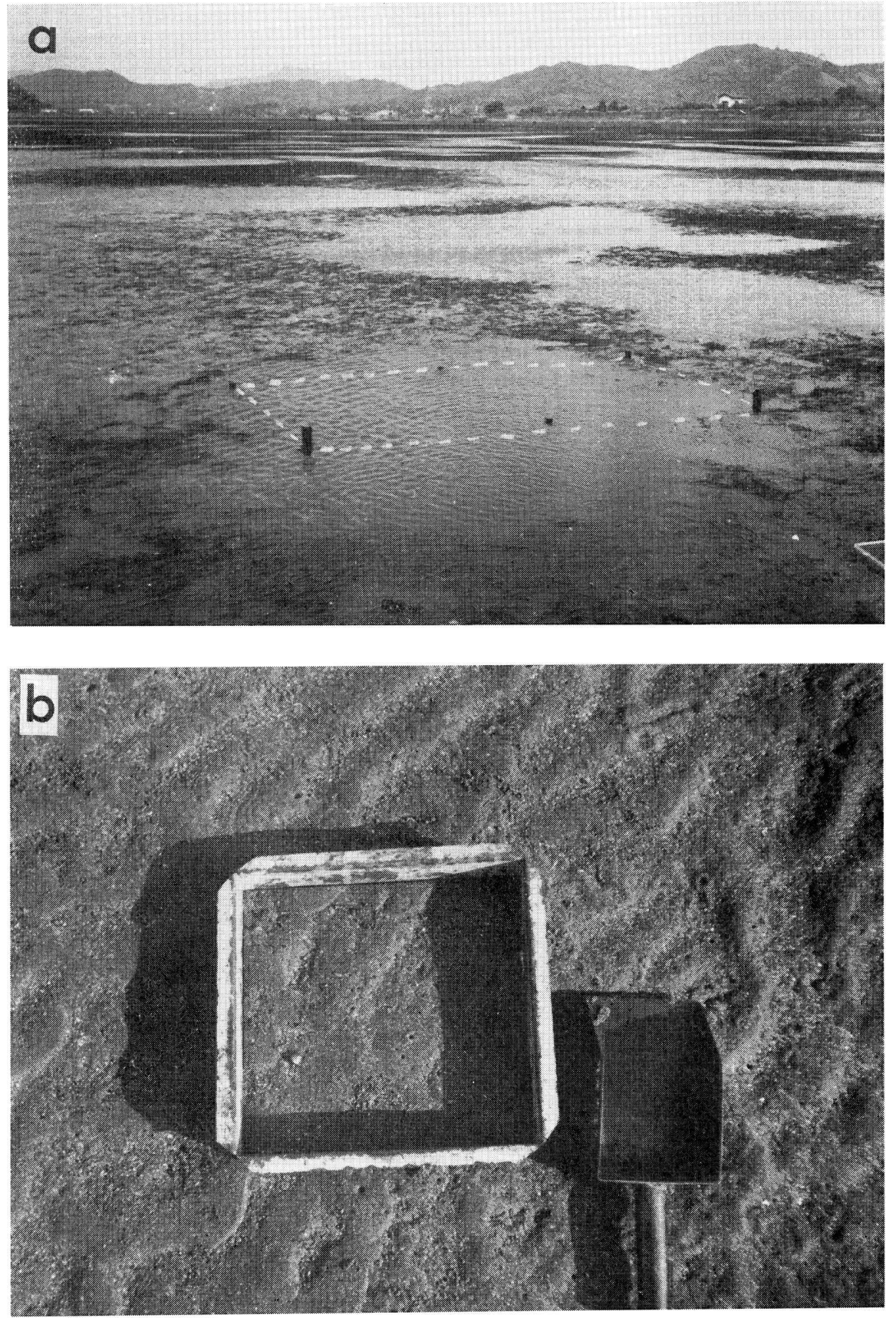

Fig. 4. a: Culturing quadrate for $M$. (M.) incongrua having an area of $1 \mathrm{~m} \times$ $2 \mathrm{~m}$. b: A steel frame of $0.25 \mathrm{~m} \times 0.25 \mathrm{~m}$ square for the quantitative sampling of living and dead shells. 
The purpose of the statistic investigation of living populations is to gather data on the primary size-frequency distribution of dead shells that are directly supplied through the mortality process of a living population.

Live samples of Macoma (Macoma) incongrua (MARTENS) were collected usually from 20 locations at bimonthly intervals from July, 1976 to July, 1978. Shell-height of all the clams sampled from quadrate $1 \mathrm{~m} \times 1 \mathrm{~m}$ (16 unit samples) were measured using a slide caliper (Fig. 2). Size-frequency histograms of living populations were then provided. Marking technique was used to obtain data on growth and mortality of each individual under the natural condition. The data provide knowledge on growth and mortality rate of populations Marking was made by attaching a piece of coloured soft-plastic chip on the shell with a fast-drying binding agent. Due to the difficulties in practice, the clams less than $5 \mathrm{~mm}$ in shell-height were omitted from the marking. Marked clams were released in $1 \mathrm{~m} \times 2 \mathrm{~m}$ quadrates, that were staked at four corners (Fig. 4-a) in the study area and two months later their shells were measured again.

Dead shells in the bottom sediments of "Irie" were investigated at many locations in order to find out whether the primary size-frequency distribution of dead shells, that were directly produced through the mortality process of living population, was maintained or not. If the size-frequency distributions of dead shells in the sediments are significantly different from the primary pattern, the cause of the modification should be found out. Quadrate with an area of $0.5 \mathrm{~m} \times 0.5 \mathrm{~m}$ was dug out to a depth of $0.15 \mathrm{~m}$ at about 150 localities. The dug sediments were sieved through a $1 \mathrm{~mm}$ screen. Dead shells larger than $1 \mathrm{~mm}$ in shell-height were measured. The size-frequency distributions of dead shells from the respective bottom sediment samples are shown by histograms, from which size-specific "survivorship" curves are reconstructed. Systematic collection of dead shells at localities deeper than $1 \mathrm{~m}$ at ebb tide in the channel and outside the inlet were made using a $0.25 \mathrm{~m} \times 0.25 \mathrm{~m}$ Ekman-Birge bottom sampler.

\section{Results}

1. Process of dead shell production in living population

The distribution of living $M$. (M.) incongrua in "Irie", is shown in Fig. 5. Living population of the species is found in the mud flat on which sea grass Zostera nana RoTH or $Z$. marina LINNAEUS grows. The average population density $M$. (M.) incongrua is about 12 to 16 individuals per square meter. Maximum population density sometimes reaches 50 individuals per square meter at the locations in the inner part of the inlet (Fig. 6). The population of the mud clam in the inlet shows random distribution.

Mud clams larger than $10 \mathrm{~mm}$ in shell-height normally burrow into the sediments approximately $0.05 \mathrm{~m}$ to $0.15 \mathrm{~m}$ below the bottom surface. At high tide, mud clam extends its inhalant siphon above the bottom surface, and sucks in detritus, which are then sorted on the gills. The feeding habit is almost the same as the feeding of Scrobicularia plana (DaCosta) (see, Hughes, 1969).

According to field observations in March, 1977, a strong correlation exists 
between burrowing depth and shell-height so far as individuals larger than 10 $\mathrm{mm}$ in shell-height are concerned. Juvenile clams smaller than $10 \mathrm{~mm}$ do not burrow appreciably, but creep on the mud surface.

Juveniles recruited in the year begin to burrow in the bottom sediments from following autumn to winter. As a general rule, number of juveniles is smaller than that of adults. From July, 1976 to July, 1978, samples for measurements were obtained from the bottom sediments of eighty quadrates of $0.25 \mathrm{~m}$ $\times 0.25 \mathrm{~m}$. The samples were collected at randomly selected locations on the before mentioned grid at bimonthly intervals.

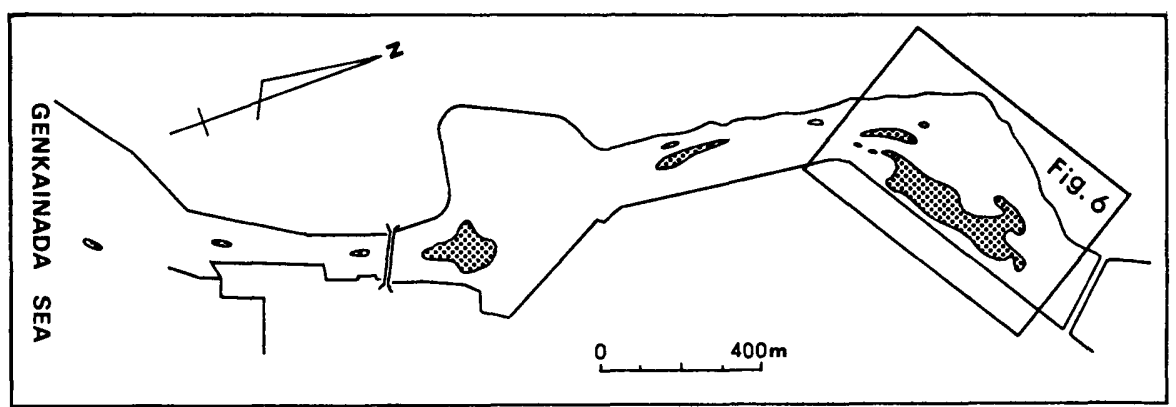

Fig. 5. Distribution of living $M$. (M.) incongrua (dotted portion).

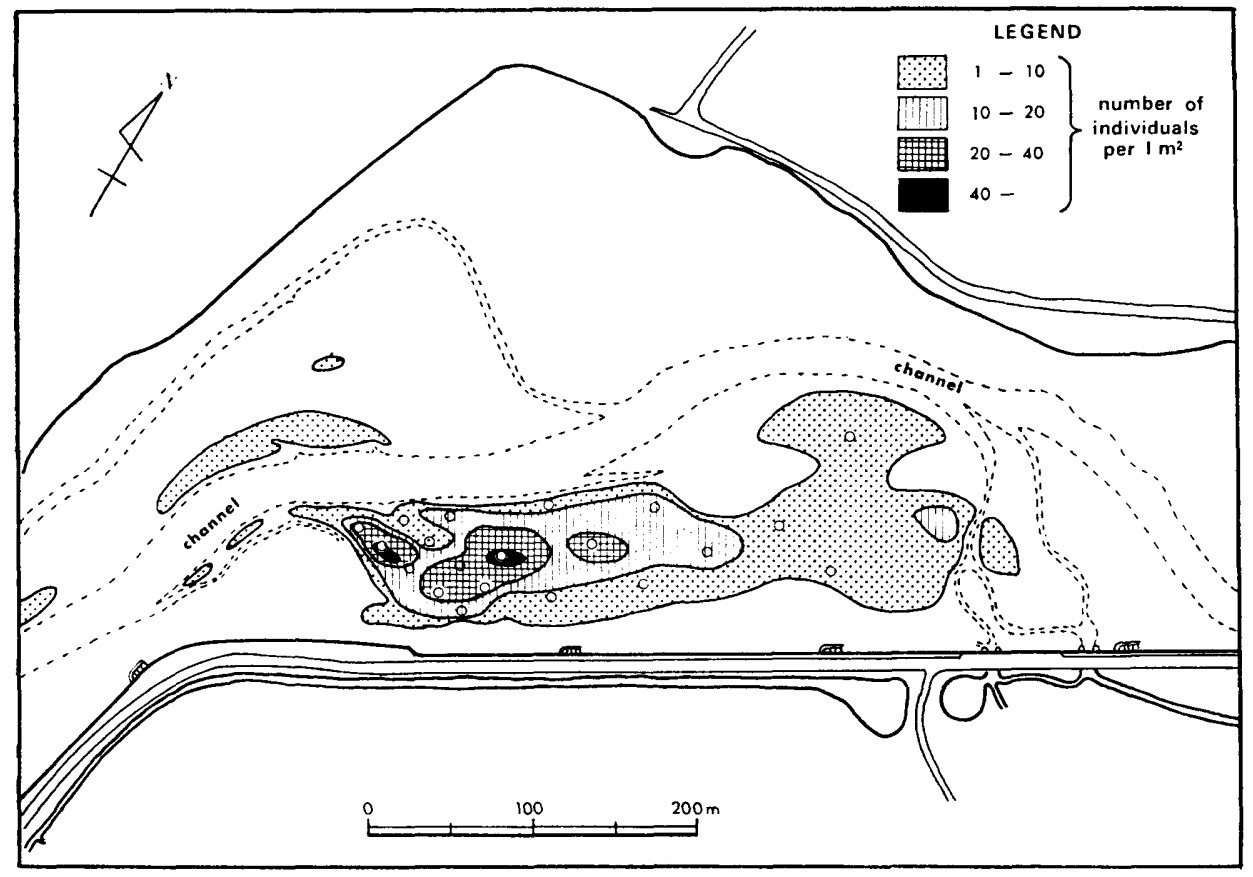

Fig. 6. Distribution and density of living $M$. (M.) incongrua on the mud flat in the innermost part of the inlet. Open circles are bimonthly collecting locations. 
Table 2. The regression equations of shell-height in one month

$\left(\mathrm{H}_{n}\right)$ and shell-height in successive two months $\left(\mathrm{H}_{n+1}\right)$.

\begin{tabular}{clllll}
\hline$n$ & $n+1$ & $r^{2}$ & $a$ & $b$ & $N$ \\
\hline Jul. & Sep. & 0.99 & $\mathbf{1 . 2 1}$ & 0.94 & 43 \\
Sep. & Nov. & 1.00 & 0.09 & 1.00 & 65 \\
Nov. & Jan. & 1.00 & 0.42 & 0.98 & 62 \\
Jan. & Mar. & 0.99 & 1.20 & 0.95 & 60 \\
Mar. & May & 0.91 & 3.28 & 0.84 & 67 \\
May & Jul. & 0.98 & 1.11 & 0.95 & 67 \\
Jul. & Sep. & 1.00 & 0.35 & 0.98 & 62 \\
Sep. & Nov. & 1.00 & 0.45 & 0.98 & 62 \\
Nov. & Jan. & 1.00 & 0.96 & 0.95 & 52 \\
Jan. & Mar. & 0.99 & 1.43 & 0.93 & 48 \\
Mar. & May & 0.98 & 2.54 & 0.87 & 46 \\
May & Jul. & 0.98 & 2.68 & 0.87 & 41 \\
\hline
\end{tabular}

$\left(\mathrm{H}_{\mathrm{n}} \mathrm{mm}\right)$ to $\left(\mathrm{H}_{\mathrm{n}+1} \mathrm{~mm}\right): \mathrm{H}_{\mathrm{n}+1}=\mathrm{b} \mathrm{H}_{\mathrm{n}}+\mathrm{a}$

$\mathrm{N}$ : sample size

$r$ : correlation coefficient

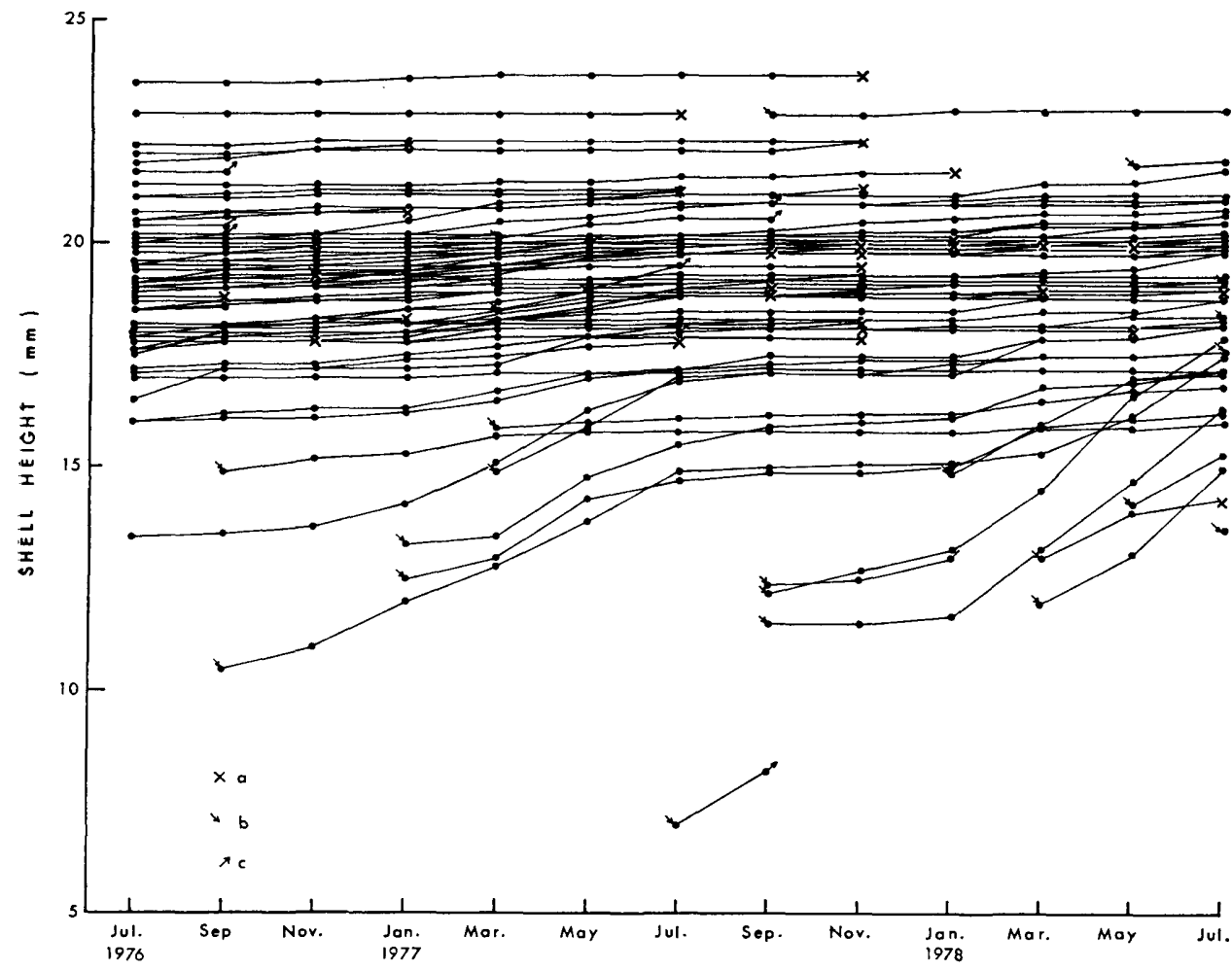

Fig. 7. Bimonthly increment in shell-height of $M$. (M.) incongrua in a quadrate of $1 \mathrm{~m} \times 2 \mathrm{~m}$. a: death of a clam, b: recruitment of a clam to the quadrate, c: escape of a clam from the quadrate. 
Marked clams were released in the specified quadrates. That is to say, four quadrates of $1 \mathrm{~m} \times 2 \mathrm{~m}$ were chosen in the central part of the distribution area of living clams, and marked clams were released into each quadrate. Two quadrates of $1 \mathrm{~m} \times 2 \mathrm{~m}$ were dug out for the purpose of gathering accurate data on annual mortality and growth rate of clams. The clams were measured at bimonthly intervals from July, 1976 to July, 1978. Another two quadrates of $1 \mathrm{~m} \times 2 \mathrm{~m}$ were set for purpose of estimating the interference of the measurement procedure on growth. The quadrates were dug out a year or two years later. A linear function is obtained from the measurements of shell-height by successive observations of bimonthly intervals and the mean growth rate per two months can be estimated from the function. The regression equation was calculated as shown in Table 2.

The shell growth rate of the species is high in spring and summer, and it is more rapid in smaller clams than in larger ones. The processes of shell growth and death of 97 clams in location of the inlet during years are shown

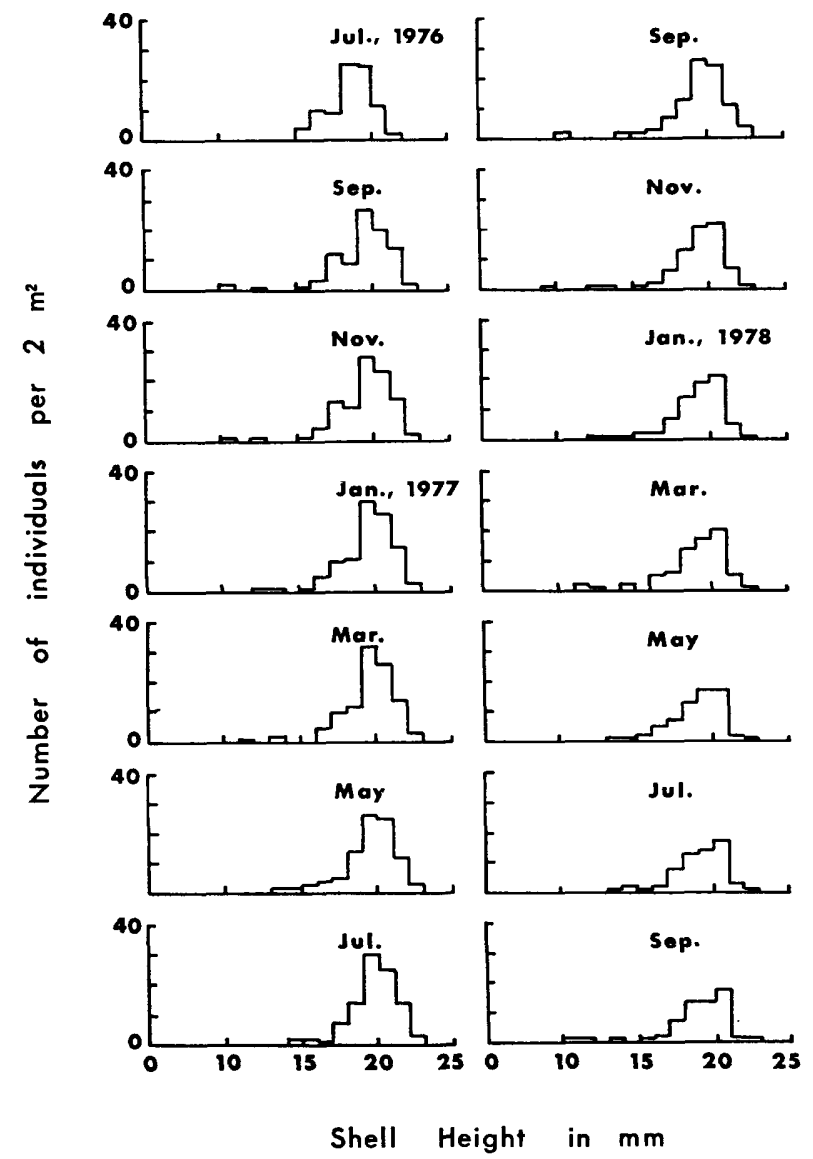

Fig. 8. Seasonal change in the size-frequency distribution of living $M$. (M.) incongrua. 
in Fig. 7. It is clearly indicated that younger clams show a larger growth rate than the adult animals, and that the shell growth is stagnated in the sizeclasses above $18 \mathrm{~mm}$ in shell-height.

The mortality rate of living population through growth stages may be estimated from bimonthly analysis of shell growth of the marked clams and the seasonal change of their size-frequency histograms (Fig. 8). Size-frequency

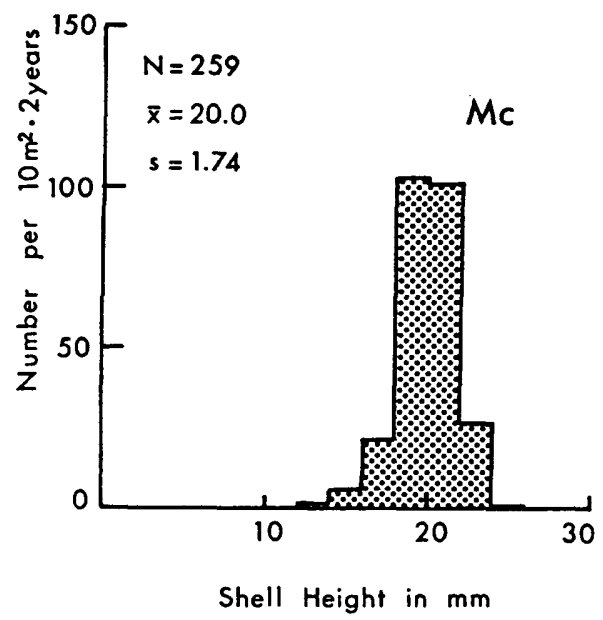

Fig. 9. Primary pattern of size-frequency distribution of dead shells of $M$. (M.) incongrua that have been derived directly from a living population during two years from July, 1976 to July, 1978.

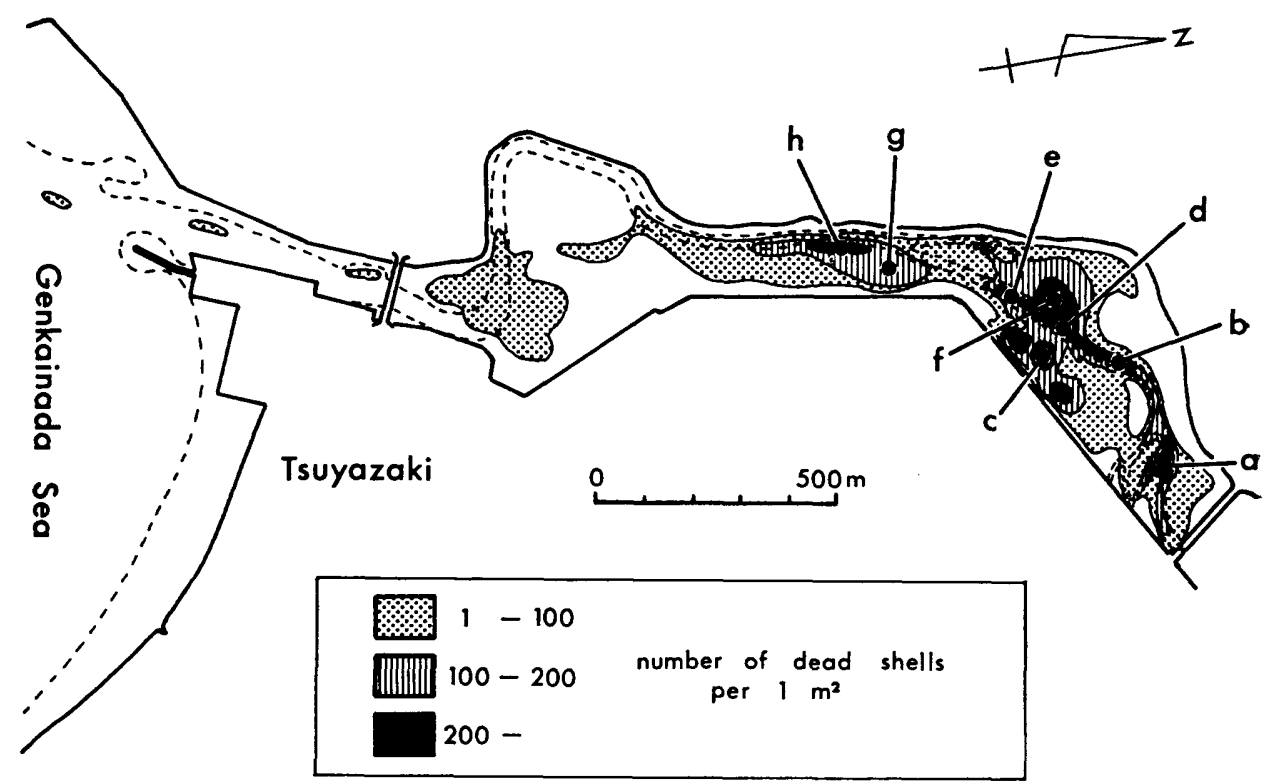

Fig. 10. Distribution of dead shells of $M .(M$.$) incongrua in the inlet. a to h$ : sampling locations of the dead shell samples in Fig. 11. 

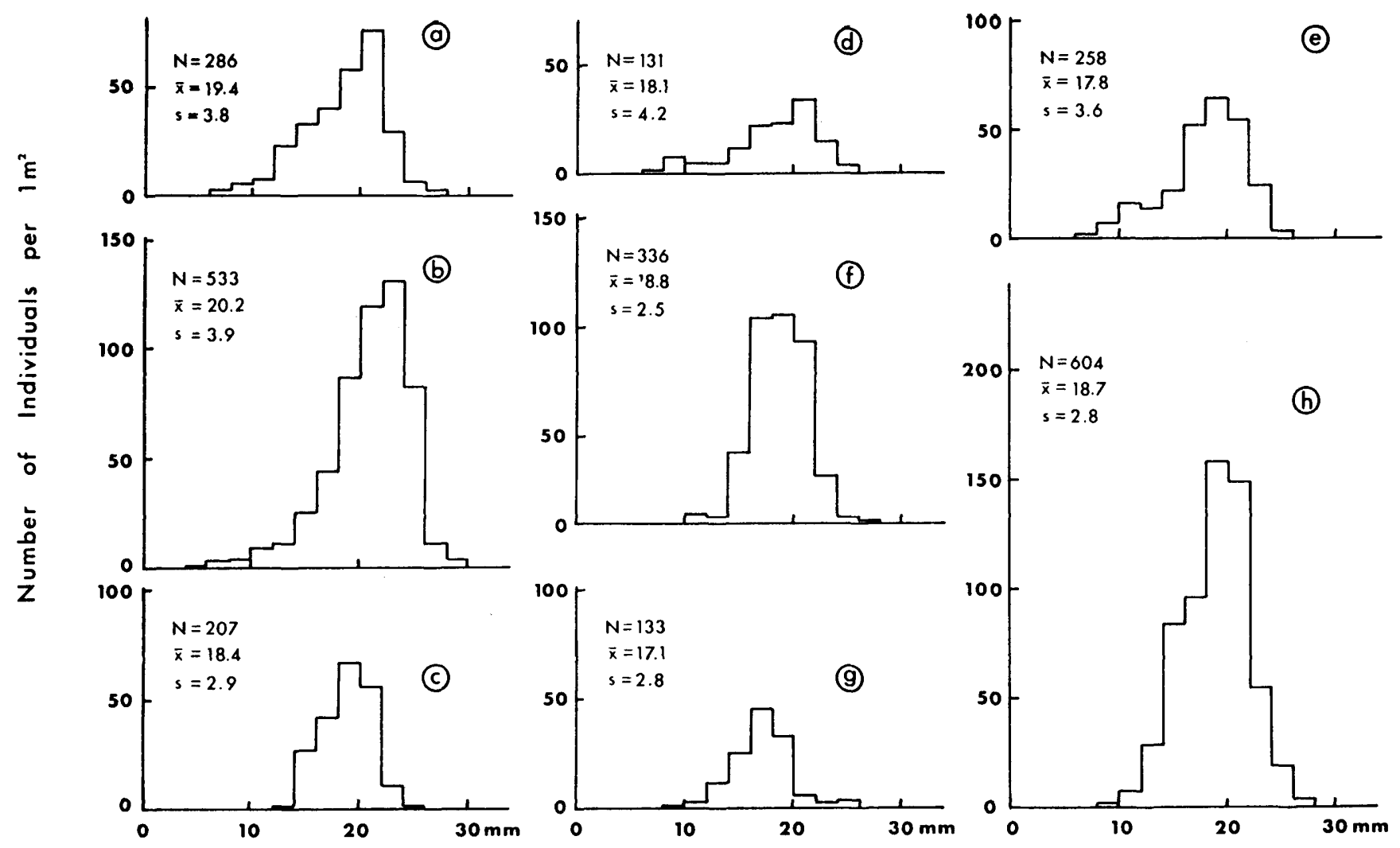

0
0
0
0
0
0
0
0
0

Shell Height

Fig. 11. Size-frequency distributions of dead shells of $M$. (M.) incongrua from the bottom sediments at eight localities in the inlet. The sampling locations are shown in Fig. 10. 
distribution of dead shells derived from living population at the interval from July, 1976 to July, 1978 is summarized in Fig. 9. This figure represents the "primary" unmodified pattern of the size-frequency distribution of the dead shell population.

The size-specific survivorship curve of the living population, obtained from bimonthly analysis of mortality, is shown as a dotted line, s.l., in Fig. 12. In the figure the initial number of population is assumed to be 1000 individuals per square meter.

The primary pattern of the size-frequency distribution of the dead shell population is characterized by a large mortality in the adult stage. The frequency distribution is essentially a normal curve with a small variance. Sample mean of the shell-height ranges from 18 to $22 \mathrm{~mm}$ in the central part of the habitat.

2. Distribution, size-frequency distribution, and size-specific "survivorship" curves of dead shell assemblages

The distribution and relative abundance of dead shells of $M$. (M.) incongrua are shown in Fig. 10. Distribution of the dead shells overlaps widely that of the

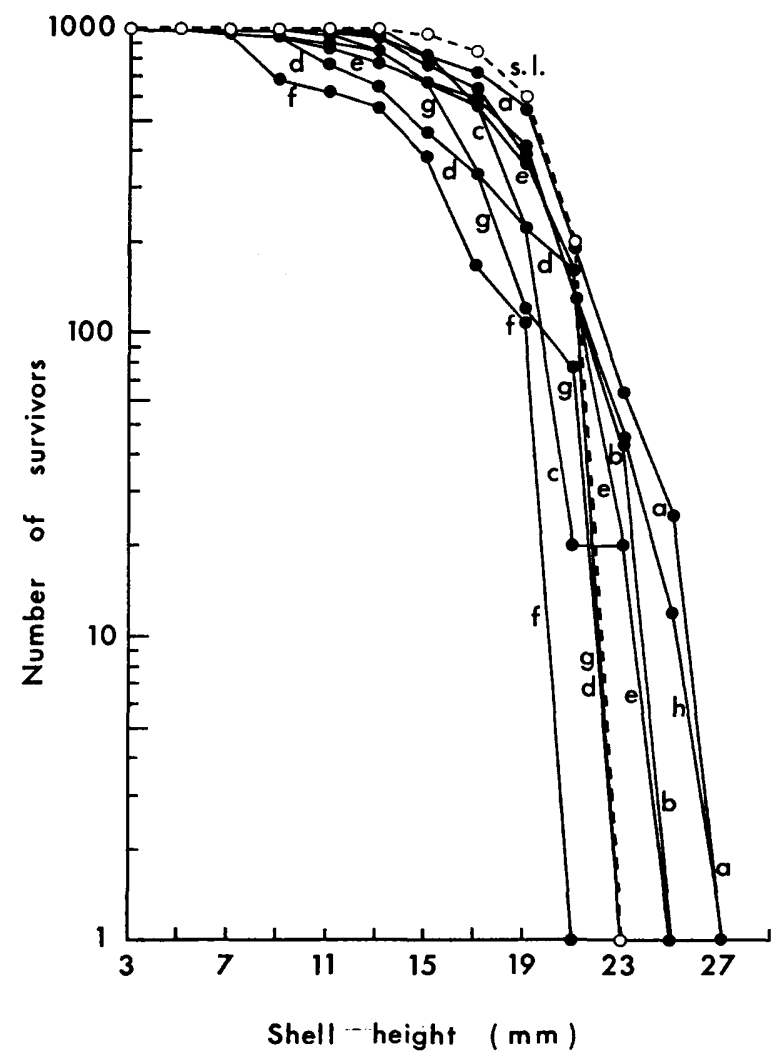

Fig. 12. Size-specific survivorship curves of $M$. (M.) incongrua. The data are obtained from the histograms in Fig. 11. Dotted line shows a survivorship curve of a living population. 
living population. The dead shells are concentrated on the mud flat and the bottom of the inlet. Maximum number of dead shells attains more than 200 individuals per square meter at several locations in this inlet. These locations on the mud flat are coincident approximately with the high density area of the living clams.

The size-frequency distribution of dead shells at eight locations ( $a, b$, c, ... and $h$ ) is shown in Fig. 11. The size-frequency distribution patterns of dead shell samples from various locations resemble that of the living population in having a small mean size and a small standard deviation except for $a, b, d$ and e which came from the channel (Fig. 9). The size-specific "survivorship" curves reconstructed from the size-frequency histograms of dead shell samples are shown in Fig. 12. They are superficially similar to that of the living population. However, the size-frequency histograms of the samples from the channel show a much larger variation than that of living population. It is probably suggested that the dead shells in the channel are composite in origin derived from several dead shell "populations" with different mean size.

\section{Discussion and Conclusions}

1. The "primary" pattern of size-frequency distribution of the dead shell assemblage and the survivorship curve of the living population of $M$. (M.) incongrua

The "primary" size-frequency distribution pattern of dead shells derived directly from living population is shown in Fig. 9. The size-specific survivorship curve of the living population, obtained from bimonthly analysis of the mortality rate, is shown as the dotted line, s.l., in Fig. 12. As shown in this figure, larger mortality in the young ontogenetic stage larger than $3 \mathrm{~mm}$ in shell-height is not recognized, but, in contrast with this, a larger mortality rate in the early mature stage is recognized. Information about settlement of metamorphosed larvae is not available because of the method adapted in the present study. However, recruited juveniles of a small number appear constantly from autumn to winter every year in the burrowing habitat of this species.

Number of the yearly recruitments is usually smaller than that of the adult clams in a population. It takes two or three years for the juvenile clams of approximately $10 \mathrm{~mm}$ to grow up to the adult size-class with a shell-height of approximately $18 \mathrm{~mm}$. In spite of high rate of mortality in the adult size-class of this species, the death in the premature stages is relatively small in number. A great number of dead shells of the species at burrowing stage is found in adult size-class having a shell-height of approximately $19 \mathrm{~mm}$. So the mode in the primary size-frequency histogram of the dead shells nearly overlaps the model size-class of a living population at burrowing stage, although the mean value of the former is smaller than that of the latter (Figs. 9 and 11). The sample standard deviation of the size-frequency of the dead shells aproximately coincides with that of the living animals and is confined to less than 3.0. The average of the adult size of a living population slightly changes by place within the inlet. Therefore the mean value of the primary size-frequency histogram 
of the dead shells derived directly from living population also slightly changes among samples from different areas in the inlet.

As a general rule, survivorship curve is expressed by the number of survivors in every age class, but palaeontological survivorship curve is expressed as size-specific survivorship curve, because the latter method is more practical than the former in treating fossil shell assemblages.

I think that the mortality rate of $M$. (M.) incongrua calculated on the basis of bimonthly analyses of a caged population in the culturing quadrate is probably overestimated, because I repeatedly disturbed the natural life in burrowing by digging out the marked clams from the muddy sediments every two months. This procedure might induce a larger mortality of clams than under natural conditions. This expected experimental error is evaluated through a comparison between the number of dead shells in the above mentioned cage and those in another cage that has been left along for two years. Two cages were set in the neighbouring areas. The error in the estimation of the mortality rate owing to the repeated disturbance attains 15 percent at most. As the error is, however, considered to have been random in all the size-classes, error has no appreciable influence on the basic pattern of the size-specific survivorship curve, if the tolerance for disturbance mentioned above is the same among individuals of different size-classes.

2. Size-frequency distribution and size-specific survivorship curve of dead shells in bottom sediments in Irie

Density of dead shells of the species in the bottom sediments $(0.15 \mathrm{~m}$ in depth) is shown in Fig. 10.

In this deep burrowing species, $M$. (M.) incongrua, no significant difference exists among size-frequency histograms of dead shell assemblages in the bottom sediments (Fig. 11). However, a slight difference is seen in the histograms that may be attributed to a difference in size-frequency among original living populations. In fact, mean values of the size-frequency distribution differ slightly from one another among living samples from different localities. They vary from 17.0 to $20.5 \mathrm{~mm}$. This variation is probably caused by different growth condition in different localities within the distribution range of species, and becomes, in turn, a cause of the variation in the mode of the size-frequency distribution of dead shell assemblages. Dead shell assemblages from the bottom surface of the channel show a tendency toward a normal distribution of sizefrequency with a large variance as a result of duplication of many dead samples of different origin with a different mean size. It is noteworthy, however, that the dead shell assemblages from channel still keep the basic patterns of the primary size-frequency distribution of the dead shells derived directly from the living population.

3. Preservation of the primary information

Degree of preservation of primary information on the size-frequency distribution of a dead shell assemblage derived directly from the living population is determined by many different factors, especially by the ecological characteristics 
of species. Pattern of primary size-frequency distribution is controlled by several main factors; annual change of absolute number of recruits, a ratio of number of recruits to the number of adults, growth and mortality rate of recruits, length of a generation, etc. as already pointed out by many authors.

Boucot (1953), Craig and Hallam (1963), Fagerstrom (1964), Hallam (1967), HALLAM (1972) and some other palaeontologists discriminated between autochthonous unmodified assemblages and allochthonous modified assemblages on the basis of the generalized patterns of the size-frequency distribution of "fossil population". It is, however, difficult to estimate the degree of preservation or modification of the primary data on the basis of the generalized patterns of size-frequency distributions, because the primary pattern of sizefrequency distribution of dead shells derived directly from the living population basically reflects ecological characteristics of the species in question and differs species by species (Shimoyama, 1979 a). Furthermore, the important factors controlling size modification, i.e. transportation and residual concentration of dead shells by water currents, and destruction of shell by a predator, do not act randomly on all the size-classes of dead shells. It maybe inferable that the size modification by physical factors is much more remarkable on the shallow bottom on an open coast than in a sheltered bay.

Further studies on the population structures of shell-bearing organisms are necessary for the future advancement of the palaeoecology.

\section{Acknowledgements}

I would like to express my sincere thanks and deep gratitude to Professor T. Shuto of Kyushu University for his continued guidance and valuable suggestions during the course of the present study. My cordial thanks are also due to Professor T. Kikuchi of Amakusa Marine Biological Laboratory, Kyushu University, Dr. T. Ozawa of Hyogo University of Education and Dr. S. Goshima of Hokkaido University for their kind and helpful suggestions during the course of this study, Professor T. Shuto, and T. Ozawa kindly reviewed the manuscript. I owe gratitude to Professor Y. Yone and other staff members of the Tsuyazaki Fisheries Research Laboratory, Kyushu University, who provided facilities for the field work.

\section{Referenced Cited}

Boucot, A. G. (1953) : Life and death assemblages among fossils. Amer. Jour. Sci., 251, 25-40.

BRookfield, M. E. (1973) : The life and death of Torquirhynchia inconstans (Brachiopoda, Upper Jurassic) in England. Palaeogeogr. Palaeoclimat. Palaeoecol., 13, 241-259.

CraIG, G. Y. and Hallam, A. (1963): Size-frequency and growth ring analysis of Mytilus edulis and Cardium edule, and their Paleontological Significance. Palaeont., 6, 731-750.

Craig, G. Y. and Oertel, G. (1966) : Deterministic models of living and fossil populations of animals. Quart. Jour. Geol. Soc. Lond., 122, 315-355. 
CraIG, G. Y. (1967): Size-frequency distributions of living and dead populations of pelecypods from Bimini, Bahamas. Jour. Geol., 75, 34-45.

DeEvey, E. S. Jr. (1947): Life tables for natural populations of animals. Quart. Rev. Biol., 22, 283-314.

Deevey, E. S. Jr. (1950): The probability of death. Scient. Amer., 182, 58-60.

Fagerstrom, J. A. (1964): Fossil communities in paleoecology: their recognition and significance. Geol. Soc. Amer. Bull., 75, 1197-1216.

HALlAM, A. (1967): The interpretation of size-frequency distributions in molluscan death assemblages. Palaeont., 10, 25-42.

HALlAM, A. (1972) : Models involving population dynamics. In Schopf, T. J. M. ed., Models in Paleobiology. Freeman, Cooper, and Campany, San Francisco, 62-80.

HofFman, A. (1976): Mortality patterns of some bivalves from the Badenian (Miocene) Korytnica Clay, Poland. Neus Jarb. Geol. Palaeont. Monatsh, Ht. 6, $337-349$.

Hughes, R. N. (1969): A study of feeding in Scrobicularia plana. Jour. Mar. Biol. Ass. U.K., 49, 805-823.

Kurten, B. (1964) : Population structure in palaeoecology. In IMBrie, J. and Newell, N. eds., Approaches to Paleoecology. Wiley, New York, 91-106.

MITRA, K. C. (1958) : Variation in Goniorhynchia boueti from Normandy and Dorset. Jour. Paleont., 32, 992-1006.

Richards, R. P. and Bambach, R. K. (1975): Population dynamics of some Paleozoic brachiopods and their Paleoecological significance. Jour. Paleont., 49, 775-798.

Richmond, N. D. (1965): Perhaps juvenile Dinosaurus were always scarce. Jour. Paleont., 39, 503-505.

RUDWICK, M. J. S. (1962) : Note on the ecology of brachiopods in New Zealand. Roy. Soc. N. Z. Trans., 25, 325-335.

Shimoyama, S. (1979a): Analysis of size-frequency distributions in living population and dead shell assemblages of some embayment molluses and its paleoecological implication, D. Thesis, Kyushu University.

Shimoyama, S. (1979b) : Effect of the size-specific utilization by intertidal hermit crabs upon the size-frequency distribution of dead shells of snail (in Japanese). Mar. Sci. monthly, 11, 527-535.

STUMP, T. E. (1975): Pleistocene molluscan paleoecology and community structure of the Pueruto Libertad Region, Sonora, Mexico. Palaeogeogr. Palaeoclimat. Palaeoecol., 17, 177-226.

THAYER, C. W. (1977) : Recruitment, growth, and mortality of a living articulate brachiopod, with implications for the interpretation of survivorship curves. Paleobiol., 3, 98-109.

VEEver, J. J. (1959): Size and shape variation in the brachiopod Schizophoria from the Devonian of Western Australia. Jour. Paleont., 33, 888-901.

Ziegler, A. M., Boucot, A. J. and Sheldon, R. P. (1966): Silurian Pentamerid brachiopods preserved in position of growth. Jour. Paleont., 40, 1032-1036. 